while the oxygen is set free, and a considerable quantity of it is converted into the more condensed form of ozone.

On taking the apparatus to pieces after each experiment, the hydrofluoric acid remaining was found to contain a small quantity of platinum fluoride in solution, and a black mud consisting of a mixture of iridium and platinum in suspension. The negative electrode was not attacked, but the platinum rod forming the positive pole was eaten away to a point, so that one rod only served for two experiments. The average delivery of gas was about 1.5 to 2 litres per hour.

With regard to the chemical processes involved in the electrolysis, it appears probable that potassium fluoride is first decomposed into fluorine, which is evolved at the positive pole, and potassium, which decomposes hydro. fluoric acid, liberating its equivalent of hydrogen at the negative pole, and re-forming potassium fluoride, which may again be electrolyzed. Hence a small quantity of the double fluoride can serve for the decomposition of a comparatively large amount of hydrofluoric acid.

The double fluoride HF. KF is very soluble in hydrofluoric acid, forming a crystallizable compound, richer in hydrofluoric acid than $\dot{H F} . K F$, and which gives off no acid vapour at the boiling-point of the anhydrous acid, $19^{\circ} 4$. It is this compound which one ought to seek to obtain for electrolysis, as it is very soluble in excess of acid, forming a liquid of good conductivity.
The double fluoride $\mathrm{HF} . \mathrm{KF}$ itself was finally electrolyzed by M. Moissan. It fuses at $140^{\circ}$ to a colourless liquid which is quite suitable for electrolysis. The experiment was performed, as before, in a platinum U-tube, and, on passing the current, fluorine was again liberated at the positive pole, and at once set fire to crystalline silicon; but the platinum was strongly attacked, so the experiment was stopped in order to save the tube. On plunging a couple of platinum wires connected with the battery into a quantity of the fused double fluoride contained in a platinum crucible, gas was evolved in abundance at each pole, and on bringing the wires in contact, even in the dark, detonation occurred, owing to the combination of the evolved hydrogen and fluorine. At the same time the platinum wire from which the fluorine was evolved was almost entirely eaten away.

In concluding these remarkable researches, which have happily terminated so successfully, M. Moissan discusses very fully the question of the identity of the gas liberated at the positive pole with the element fluorine; and there can be no doubt that he has completely proved this identity, at the same time showing that fluorine occupies the place of honour as the most intensely active chemical element with which we are at present acquainted, and that it assumes its rightful position, theoretically destined for it, at the head of the group of halogens.

A. E. Tutton.

\section{TIMBER, AND SOME OF ITS DISE.ASES.} I.

( $\mathrm{N}$ carefully examining the clean-cut end of a sawn $\log$ of timber, it is easy to convince ourselves of the existence of certain marks upon it, which have reference to its structure. These marks will vary in intensity and number according to the kind of tree, the age at which it is felled, and some other circumstances, which may be overlooked for the present; but in a given case it would be possible to observe some such marks as those indicated in Fig. I. In the specimen chosen there is a nearly central spot, the pith, around which numerous concentric lines-the "annual rings"-run. Radiating from the pith towards the periphery are cracks, the number, and length, and breadth of which may vary according to the time the $\log$ has been exposef to the weather, and other circumstances; these cracks are due to the contraction of the wood as it "shrinks," and they coincide with medullary rays, as lines of weakness. Between these cracks are to be seen numerous very fine radiating lines indicating the course of the uninjured medullary rays, which again will vary in distinctness, \&c., according to the species of timber.

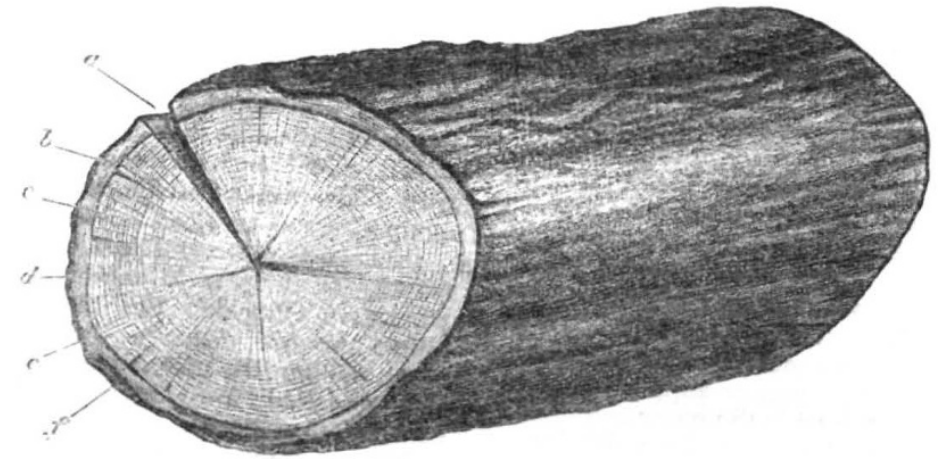

FIG. r.-A $\log$ of timb r, showing radial cracks after lyinz expozed for some time, $a$, a large crack extending from pith to circumference $; b$, the cortex; $c$, medullary ray $; d$, canbium; $e$, annual ring; $f$, outer bark, proper. Reduced.

This log of wood, with its annual rings and medullary rays, is clothed by a sort of jacket, consisting of cork and softer tissues, and termed the cortex, or, more popularly, the "bark" (an unfortunate word, which has caused much trouble in its time). The largest of the cracks is seen to traverse the whole radius of the face of the wood from centre to circumference, and also to pass through the cortex, which gapes widely.

The remaining cracks, however, stop short at a line which marks on the one hand the inner face of the cortex, and on the other the outer face of the wood: this line also represents the cambium, a thin sheet of generative tissue which remains after giving rise to practically the whole of the wood (a very little in the centre excepted) and cortex visible in the woodcut. Since we are not concerned with the cortex and bark at present, it will be convenient to regard the log as "barked," and only deal with the wood or timber itself, in the condition to which the woodman reduces it after removing the cortex with certain implements.

If now we split such a $\log$ as Fig. I along the line or the big crack, neatly and smoothly, the well-known "grain" so often observed on planks of wood will come into view, and it will be noticed that the lines which mark the "grain" are continuations of the lines which mark 
the annual rings, as shown in Fig. 2, which represents on a larger scale a segment such as could be cut from a log in the way described. It is clear from comparison of what has been said, and of the two figures, that the "annual rings" are simply the expression in cross-section of cylindrical sheets laid concentrically one over the other, the outermost one being that last formed. But on examining the medullary rays in such a piece of timber as that in Fig. 2, it will be noticed that they also are the expression of narrow radial vertical plates which run through the concentric sheets: the medullary rays are in fact arranged somewhat like the spokes of a paddle-wheel of an old steamer, only they differ in length, breadth, and depth, as seen by comparing the three faces of the figure. It is to be noticed that the medullary rays consist of a different kind of tissue from that which they traverse, a fact which can only be indicated in the figure by the depth of shading. It is also to be observed that the "annual rings" show differences in respect to their tissue, as marked by the darker shading near the boundary lines on the outer margin of each ring. In order to understand these points better, it is necessary to look at a piece of our block of timber somewhat more closely, and with the aid of some magnifying power. For the sake of simplicity it will be convenient to select first a piece of one of the timbers known as "deal" (firs, pines, \&c.), and to observe it in the same direction as we commenced with, i.e. to examine a so-called transverse section.

The microscope will show us a figure like that in the woodcut (Fig. 3). There are to be seen certain angular openings, which are the sections of the long elements technically called tracheides, shown in elevation in Fig. 4. It will be noticed that whereas along some parts of the section these openings are large, and as broad in one direction as in the other, in other parts of the section the openings are much smaller, and considerably elongated in

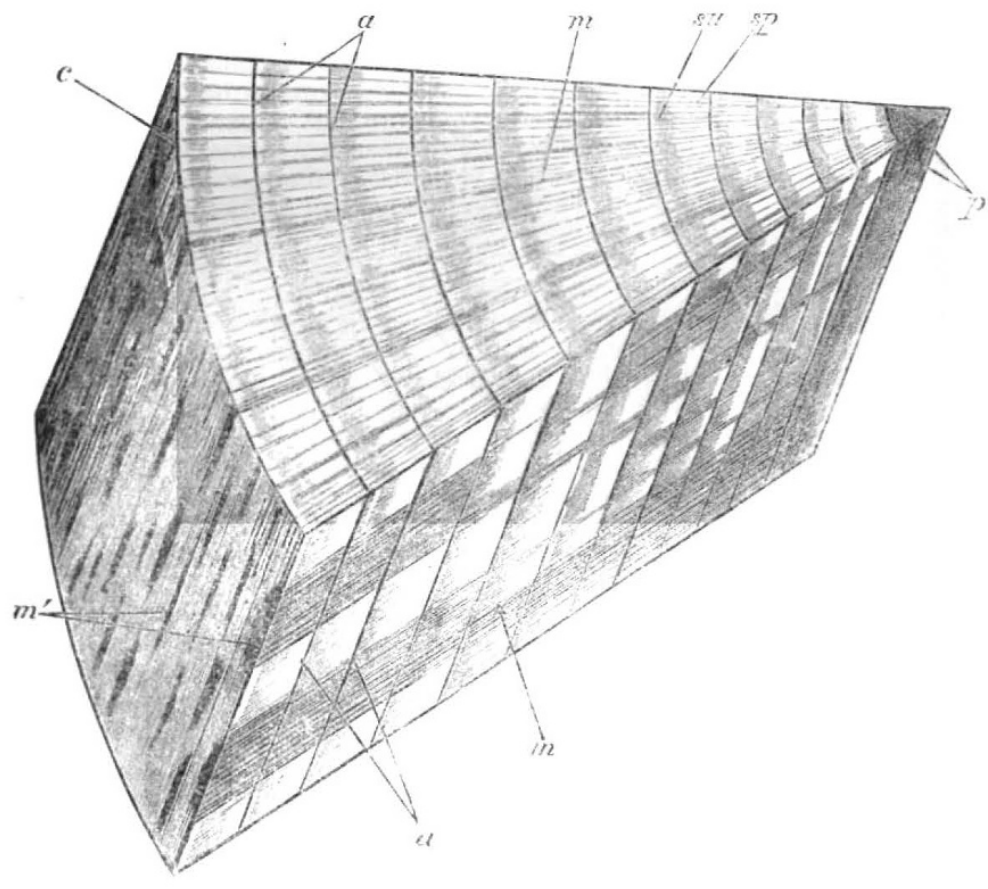

FIG. 2 .

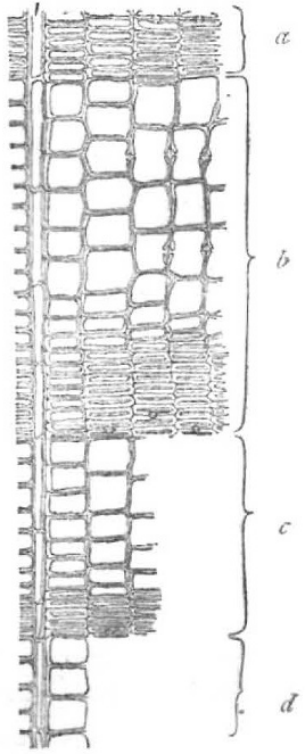

FIG. 3.

Fig. 2.-Portion of segment of wood from a log such as Fig. $x$, supposed to be slightly magnified. $a$, annual ring; $m$, medullary rays; m', the same in vertical section; $c$, the boun fary line between one annual ring and another; sll, autumn wood; sp, spring wood; $p$, the pith.

FIG. 3.-Portions of four amnual rings from a thin transverse section of the wood of a Conifer, such as the Spruce-fir. $M$, , a medullary ray; $b$ and $c$ show the entire breadth of two annual rings; $a$, autumi wo 1 of an annual ring internal to $b$ (an 1 therefore older than $b$ ); $d$, spring wood of an annual ring external to $c$ (and therefore younger than $c$ ). Bordared pits are seen in section on some of the tracheides. Magnified about roo times.

one direction as compared with the other. The band of small openings naturally looks more crowded and therefore darker than the band of larger openings, and it is to this that the differences in the shading of the annual rings in Fig. 2 are due. But it is not simply in having larger lumina or openings that the dark band of tracheides is distinguished from the lighter one : the walls of the tracheides are often also relatively thicker, and obviously a cubic millimetre of such wood will be denser and contain more solid substance than a cubic millimetre of wood consisting only of the larger, thin-walled tracheides. It is equally obvious that a large block of wood in which the proportion of these thick-walled tracheides with small lumina is greater (with reference to the bands of thin-walled tracheides) will be closergrained, and heavier, than an equal volume of the wood where the thin-walled tracheides with large lumina predominate.
Returning now to the section (Fig. 3), it is to be observed that the differences in the zones just referred to enable us to distinguish the so-called "annual rings." The generally accepted explanation of this is somewhat as follows. In the spring-time and early summer, the cambium-cells begin to divide, and those on the inner side of the cylinder of cambium gradually become converted into tracheides (excepting at a few points where the cells add to the medullary rays), and this change occurs at a time when there is ( $I$ ) very little pressure exerted on the inner parts of the trunk by the cortex and corky bark, and (2) only comparatively feeble supplies are derived from the activity of the leaves and roots, in the still cool weather and short days with little sunlight. In the late summer, however, when the thickened mas; of wood is compressed by the tightened jacket of elastic bark which it has distended, and the ling, hot, bright sunny days are causing the numerous leaves and roots to 
supply abundance of nutriment to the growing cambiumcells, it is not surprising that these cells cannot extend themselves so far in the radial direction (i.e. in a line towards the centre of the compressed stem), and that their walls are thickened by richer deposits of woody material supplied quickly to them.

As the winter approaches, the cambium ceases to be active, and it then remains dormant for several months. When its cells are awakened to renewed growth and division in the following spring, they at once begin to form the tracheides with thin walls and large lumina, and it is the sharp contrast thus displayed between the newlyformed tracheides with thin walls and large lumina, and the compressed denser ones on which they suddenly abut, that produces the impression of the "annual ring."

It is now time to attempt to give some clearer ideas of what this "cambium" is, and how its cells become developed into tracheides. But first it is necessary to point out that each tracheide is a long, more or less tubular and prismatic body, with bluntly tapering ends, and the walls of which have certain peculiar markings and depressions on them, as seen in Fig. 4. We cannot here go into the important signification and functions of these markings and depressions however, since their study would need an article to themselves. It must suffice for the present to state that the markings have reference to the minute structure of the cell-walls, and the depressions are very beautiful and complicated pieces of apparatus to facilitate and direct the passage of water from the cavity of one tracheide to that of another. Now, the cambium is a thin cylindrical sheet of cells with very delicate walls, each cell having the form of a rectangular prism with its ends sharpened off like the cutting edge of a carpenter's chisel: this prism is broader in the direction coinciding with the plane of the sheet of cambium-i.e. in the tangential direction, with reference to the trunk of the tree-than in the

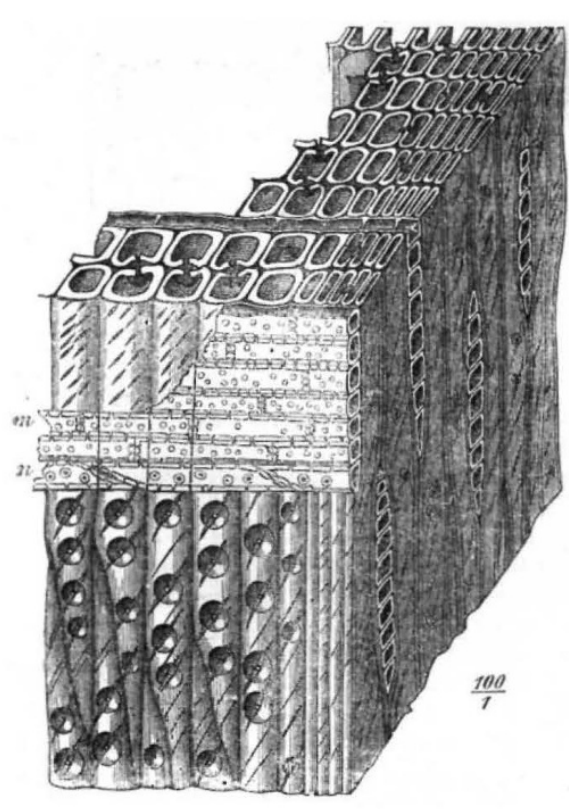

FIG. 4.

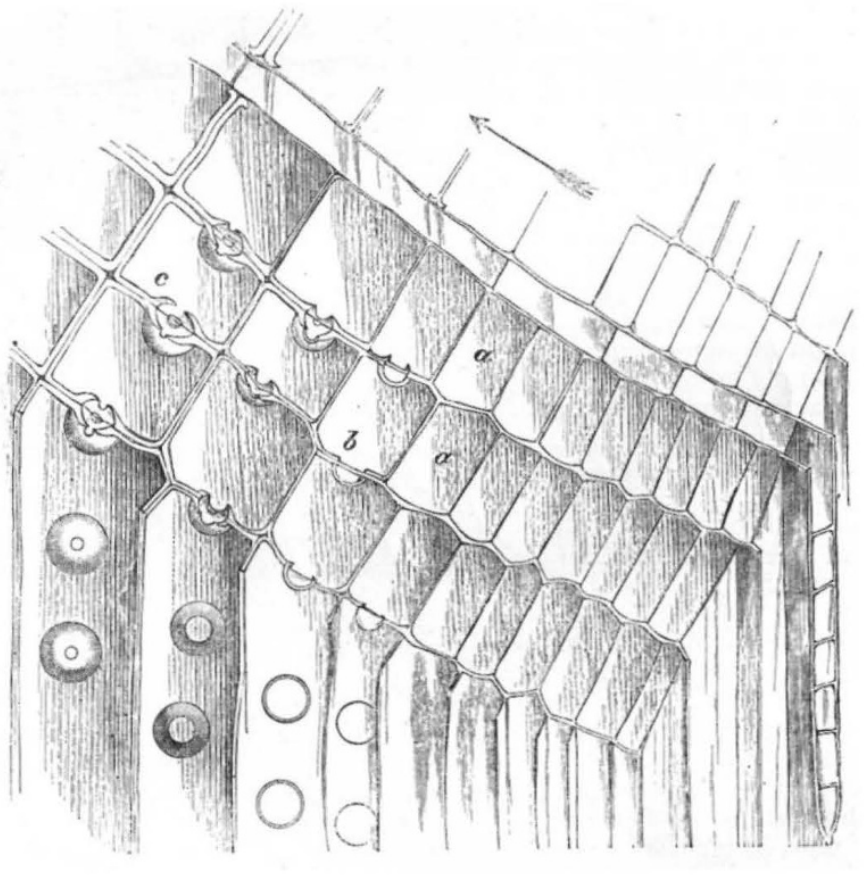

FIG. 5.

Fis. 4.-A small block of wood from a spruce-fir, supnosed to be magnified about roo times, showing elevation and sectional views of the tracheides of the

autumn (to the right) and spring wood, and medullary rays ( $m$ n) running radially between the tracheides. (After Hartig.)
FIG. 5.-Portion of cambium of a fir, showing the development of the young wood tracheides from the cambium-cells. The arrow points to centre of the stem. The cambium-cells at length cease to divide, and the walls become thicker $(a)$, except at certain areas, where the bo:dered pits are developed $(b$ and $c)$. To the right is a medullary ray. Highly magnified, and the contents of the cambium-cells omitted for clearness.

direction of the radius of the stem; and the chisel-edge must be supposed to run in the direction parallel to that of a medullary ray, i.e. radially. From the first, each cambial cell contains protoplasm and a nucleus, and is capable of being nourished and of growing and dividing. It is only at or near the tips of the branches, \&c., that these cambium-cells are growing much in length, however; and in the parts we are considering they may be for the most part regarded as growing only in the radial direction; more rarely, and to a slight extent, in the tangential direction also, as the circumference of the cylinder enlarges. After a cambial cell has extended its walls by growth in the radial direction to a certain amount, a septum or division wall arises in the longitudinal tangential plane, and two cells are thus formed in place of one: this process of division may then be repeated in each cell, and so the process goes on. This is not the place to lay stress on certain facts which show that a single layer of cells initiates the division: it suffices to point out that by the above process of division of the cambial cells there are formed radial rows of cells, as indicated in Fig. 5, where the arrow points along a radius towards the centre of the stem. It is true such radial rows of cells are also developed in smaller numbers towards the outside of the cambium cylinder (i.e. to add to the cortex), but we are only concerned with the wood, and therefore only regard those cells which are developed on the inside (i.e. towards the centre of the stem). After a time the oldest of these cells (i.e. those nearest the centre of the stem) cease to divide, and undergo changes of another kind: the process of division is still going on in the younger ones, however; and so the radial rows are being extended by additions of cells at their outer ends. (if course, this is normally proceeding along the whole area of the cylindrical sheet of cambium, and therefore over the whole of the stem and roots, with their branches. 
Confining our attention to one of the innermost, oldest cells of the cambium, which has ceased dividing ( $a a$ in Fig. 5), we find that it enlarges somewhat in the radial direction, and then its hitherto very thin walls become thicker; in fact, the protoplasm in its interior absorbs food-materials, and changes them into a peculiar substance which it plasters or builds on to the inner sides of the cell-wall, so to speak, until the wall is much thicker. This thickening process is withheld at certain places only-the thin depressions already referred to. Two chief changes result now: (I) the whole of the living contents of the young wood-cell gradually become used up, and eventually disappear without leaving any trace; and (2) the thickening substance built on to the inside of the walls undergoes changes which convert it into true wood-substance-in botanical language, the walls become lignified. The cells $b$ and $c$ in Fig. 5 illustrate what is meant.

During all these changes, which occupy several or even many hours or days, according to circumstances, it will be observed that the definitive shape of the cell is gradually completed, and then alters very little: the prismatic cambium-cell has become a prismatic tracheide, with thicker, lignified walls, and containing air and water (with minute quantities of mineral substances dissolved in it) in place of protoplasm and nutritive substances. It is not necessary here to spcak of other and more subtle changes which cause slight displacements, \&c., of these cells.

If I have succeeded in making the chief points in this somewhat complicated process clear, there will be little difficulty in explaining what occurs in other parts of the cambium-cylinder. The cambium-cells which happen to stand in the same radial row as the cells of a medullary ray, simply go on being converted into cells of the medullary ray, instead of into tracheides; cells which cliffer from the tracheides chiefly in retaining their living contents and nutritive materials-i.e. substances like starch, proteids, sugars, \&c., which are used as food by the plant. Again, those cells of the cambium which are divided off on the outer side of the cylinder (they are always fewer in number) are gradually transformed into elements of the cortex, and finally enter into the composition of the bark proper.

Now and again, but much more rarely, a radial row of cambial cells which, from their position, it would appear should be converted into tracheides of the wood, alter their destiny, so to speak, and become the originators of a new medullary ray. But I must pass cver these and some other minor peculiarities, and refer to the illustrations for further details.

If now, instead of a $\log$ of deal, or coniferous wood, we direct attention to the timber of a dicotyledonous tree, such as the oak, ash, beech, chestnut, poplar, \&c., the differences in detail will not be found very great in relation to the broad features here under consideration. Turning again to Fig. I, it would be possible to select a cut $\log$ of any of these timbers which presented all the salient characters there exhibited. The bark would present external differences in detail-such as in roughness, colour, thickness, \&c.--but it could still be described, as before, as a more or less corky jacket around the whole of the wood: the cut face would show the timber marked by more or less numerous and prominent "annual rings," traversed by smaller or larger medullary rays, radiating from the central pith, and passing across the cambium to the cortex. Moreover, cracks would be at to form on exposure, as before ; the opening occurring along the lines of medullary rays-lines of weakness.

Again, if we cut a segment of the wood, like Fig. 2, the chiet features would present themselves as there shown, and the lines of demarcation indicating the annual rings would be found to be due to the sharp contrast between the spring wood and the autumn or summer wood, as before.

On closely examining a transverse section of such a piece of timber, however, we should find differences which at first sight appear profound, but which on reflection and comparison turn out to be of more relative significance, from the present point of view, than might be expected.

Selecting a given example, that of the beech for instance, the first difference which strikes us (Fig. 6) is a number of relatively very large openings on the transverse section: these are the vessels-pitted vessels-long tubular structures which are not formed by the cambium of the conifers. Between these vessels are much more numerous elements with very small lumina and thick walls: the latter are the wood-fibres proper, and have to be technically distinguished from the apparently somewhat similar wood-tracheides of the pines, firs, \&c. Here and there, scattered in small groups, are certain rows of shorter cells, which, however, are not very numerous in the beech: they are called wood-parenchyma (Fig. 6, wp.), and occur particularly in the vicinity of the vessels.

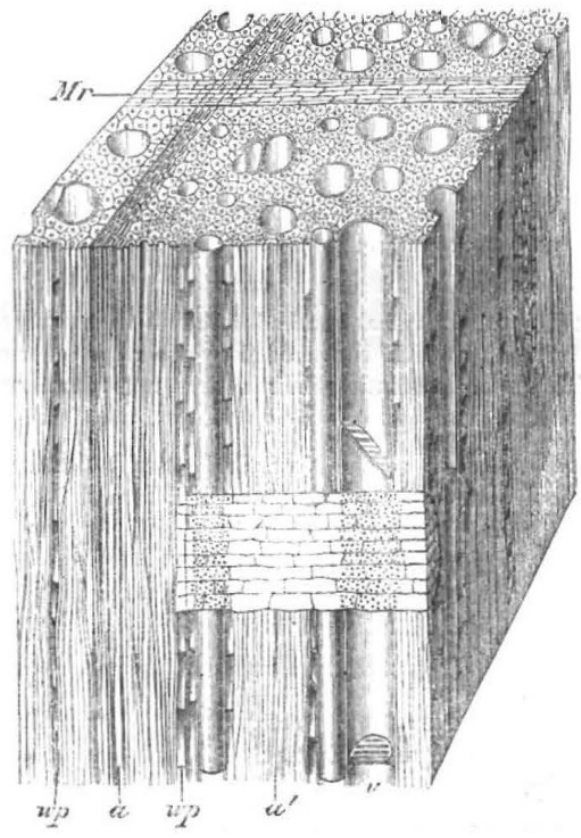

FIG. 6.-A piece of wood from a dicotyledonous tree (beech), supposed to be magnified about roo times. $M r$, a medullary ray running across the transverse section: the dark band crossed by this ray is the autumn wood (a), fo rmed of closely-crowded wood-fibres and tracheides v, a large vessel in section: others are seen also-they are smaller and timber is compose d; wp, wood-parenchyma cells.

It is beside the purpose here to describe in detail the histology of the beech-wood, and reference may be made to the figures for further particulars. It may suffice to say that all the elements-cells, fibres, and vessels-are formed as before by the gradual development of cambium, cells; and the same is true, generally, of the medullary rays here that is true of those of the pines and firs, \&c.

Attention is to be directed to the fact, which is here again evident, that the line of demarcation between any two " annual rings" is due to the suciden apposition of noncompressed elements upon closely-packed and apparently compressed elements: the latter were formed in the late summer, the former in the spring. Moreover, the spring wood usually contains more numerous vessels, with larger lumina than the autumn wood: in this particular case, again, the fibres of the autumn wood are darker in colour. It should be stated, however, that many dicotyledonous trees show these peculiarities much more clearly than the beech; others, again, show them less clearly. 
Now it is obvious that, other things being equal, the spring wood, with its more numerous and larger vessels, and its looser tissue generally, will yield more readily to lateral pressure and strains than the denser autumn wood; and the like is true of the pines and firs--the closelypacked, thick-walled tracheides of the autumn wood furnish a firmer and more resistant material than the larger, thinner-walled tracheides of the spring wood. To this point we shall have to return presently.

\section{H. MaRshall Ward.}

(To be continued.)

\section{NOTES.}

WE deeply regret to announce the death of Prof. Balfour Stewart, one of our most eminent men of science. Last Friday morning he left the Owens College, apparently in his usual health and in good spirits, intending to spend the holidays at his Irish home. He died on Sunday night. Next week we shall have something to say about his character and work.

THE death of Carl Langer, the well-known Professor of Anatomy at the University of Vienna, is announced. He was in his sixty-eighth year.

Dr. Arthur Farre, F.R.S., died on the 17 th inst., in his seventy-seventh year. He was elected a Fellow of the Royal Society in 1839 .

THE Royal Society has been admitted to the number of those public bodies to which is conceded by prescription or otherwise the privilege of presenting their addresses to the Sovereign on the throne.

THE Curatorship of the Natural History Department of the Science and Art Museum, Dublin, rendered vacant by the resignation of Mr. A. G. More, has just been filled by the promotion of Dr. R. F. Scharff, who had been one of the assistants in the Museum for some months. 1)r. Scharff has already proved himself to be a diligent student of zoology in Edinburgh, where he took the degree of Bachelor of Science. In London he studied under Prof. Ray Lankester, and worked in the British Museum for some time under the Director, Prof. Flower, F.R.S., and he obtained the degree of Doctor of Philosophy at Heidelberg University.

Mr. Jorn M. Thomson has been appointed to the Chair of Chemistry in King's College, vacant through the death of Prof. Bloxam.

AT the Central Institution, Exhibition Road, South Kensington, Dr. A. K. Miller, Demonstrator and Assistant in the Chemical Research Laboratory, will deliver, during the spring term, a course of ten lectures on the chemistry of oils and fats. The course will be delivered on Mondays at 4 p.m., and will begin on January $23,1888$.

THE third annual meeting of the American Association for the Advancement of Physical Education was held at Brooklyn on November 25. It was well attended. Papers were read by Prof. Edward Hitchcock, of Amherst College, who presided; by Prof. E. H. Fallows, of the Adelphi Academy; and by Prof. J. W. Seaver, of Yale College.

Science (December 9, 1887) notes, as a fact which may be of interest to Americans, that in England the point of view of those who argue in favour of technical edncation is almost exclusively the economic. "But little is heard," it says, "of the educa. tional nature of manual training." Speaking of the state of things in the United States, Science says:- "There is now, as is well known, a very general movement throughout this country in favour of what is known as manual training in education.
After much misapprehension and tedious explanation, the leaders of this movement have finally managed to make the educational public understand that they advocate manual training mainly for its educational value, and only incidentally for the economic benefits which will undoubtedly flow from it."

THE twentieth annual meeting of the Kansas Academy of Science was held in the Capitol Building, Topeka, on October 26 , 27 , and 28. Scicilce says that there was an excellent attendance of members, but that the local attendance was not quite equal to that of last year. The papers read, accorling to Sicince, were unusually valuable. The annual meeting next year will be held in Wichita, in October.

THe tenth general meeting of the German Society of Analytical Chemists was held at Frankfurt, on November 30 . Dr. Schmitt, of Wiesbaden, was President.

THE tenth meeting of the German Geographical Society will be held at Berlin next Easter. In future the meetings will be held only once in two years.

FifTy shocks of earthquake are reported to have occurred at Silveric, in Dalmatia, on November 29. On the same day, at 7.30 a.m., severe shocks occurred at Oran, Mascara, and Relizante, in Algeria.

Ox the evening of $\mathrm{N}$ vember $2 \mathrm{r}$, from $8.30 \mathrm{p} . \mathrm{m}$. to about 9 , a remarkable luminous phenomenon, viz. a broad band of light right across the sky, was seen throughout the whole of central and southern Sweden. It caused much speculation, chiefly on account of its luminous immobility. Dr. N. Ekholin, of the Upsala Meteorological Observatory, and well known for his researches on the aurora borealis at Spitbergen, has now pronounced the phenomenon to be a so-called auroral band. Dr. Ekholm states that such bands are very uncommon in Sweden, but that they are often seen at Spitzbercen. He saw the phenomenon during a journey from Stockholm to Upsala, at 8.45 p.m., and noted its position. The band ran then just norih of the northernmost stars in Orion, through Aldebaran, theo a little south of the Pleiades, further through the Ram, and then a little north of the two southernmost stars in the square of Pegasus. He calculates its height above the earth at about 80 miles, its zenith being perpendicular above the two provinces of East and West Gothia. The bands moved from north to south at the rate of about 50 metres per second. In Upsala it seemed south of the zenith. Dr. V. C. Gyllenskiöld made similar observations at Upsala. Dr. Flkholm invites all who may have observed the phenomenon to communicate their observations to him in the interests of science.

O. the afternoon of November 26 , at +30 , a splendid meteor was seen at Laurvik in the Christiania fjord, It went from east to west, and apparently low in the horizon. In spite of the moonlight its tail was visible for some seconds afterwards.

ONE morning last week, the Teus[jori, a little to the north of Bergen, on the west coast of Norway, was covered with ice three-quarters of an inch thick, as far as the eye could reach. Ice, in consequence of the influence of the warmth of the Gult Stream, has hitherto been unheard of on the west coast of Norway.

Symons's Monthly Meteorological Magazine for December contains an investigation of what was reported in the newspapers to have been an earthquake-shock in Central England on November 20 last. At the more western stations the reporter: spoke chiefly of noise, and at the eastern ones of earth tremor. From evidence collected, it appears that the disturbance, as Mr. Ii. G. Fordham pointed out in NATURE last week (p. 15r), was caused by the explosion of a large meteor. Further particulars 